\title{
The large tsunami of 26 December 2004: Field observations and eyewitnesses accounts from Sri Lanka, Maldives Is. and Thailand
}

\author{
Gerassimos A. Papadopoulos ${ }^{1}$, Riccardo Caputo ${ }^{2}$, Brian McAdoo ${ }^{3,4}$, Spyros Pavlides ${ }^{5}$, Vassilios Karastathis ${ }^{1}$, \\ Anna Fokaefs ${ }^{1}$, Katerina Orfanogiannaki ${ }^{1}$, and Sotiris Valkaniotis ${ }^{5}$ \\ ${ }^{1}$ Institute of Geodynamics, National Observatory of Athens, 11810 Athens, Greece \\ ${ }^{2}$ Deptartment of Structural Geology, University of Basilicata, Macchia Romana Campus—85100 Potenza, Italy \\ ${ }^{3}$ Institute of Geology, ETH Zentrum, Sonneggstrasse 5 CH8092 Zurich, Switzerland \\ ${ }^{4}$ Department of Geology and Geography, Vassar College, Box 735, Poughkeepsie, NY 12604, USA \\ ${ }^{5}$ Department of Geology, Aristotelian University of Thessaloniki, 54006 Thessaloniki, Greece
}

(Received July 15, 2005; Revised December 28, 2005; Accepted January 17, 2006; Online published February 17, 2006)

\begin{abstract}
Post-event field surveys were conducted and measurements were taken in Sri Lanka and Maldives about two weeks after the catastrophic Indian Ocean tsunami of 26 December 2004. The measurements taken were cross-checked after interviewing with local people. In the southwest, south and east coastal zones of Sri Lanka maximum water levels ranging from $h=3 \mathrm{~m}$ to $h=11 \mathrm{~m}$ a.m.s.l. were estimated. The highest values observed were in the south of the island: Galle $h \sim 10 \mathrm{~m}$, Hambantota $h \sim 11 \mathrm{~m}$. Maximum inundation of $d \sim 2 \mathrm{~km}$ was observed in Hambantota. The heavy destruction and thousands of victims caused in coastal communities, buildings and infrastructure, like railways and bridges, is attributed not only to physical parameters, like the strength of the tsunami hydrodynamic flow, coastal geomorphology and the wave erosional action in soil, but also to anthropogenic factors including the increased vulnerability of the non-RC buildings and the high population density. Local people usually described the tsunami as a series of three main waves. The leading wave phase was only a silent sea level rise of $h \leq 1.5 \mathrm{~m}$ and $d \leq 150 \mathrm{~m}$, while the second wave was the strongest one. The first two waves occurred between 09:00 and 09:30 local time, depending on the locality. It is well documented that near Galle, southern part, the strong wave arrived at 09:25:30. In the west coast the third wave was a late arrival which possibly represents reflection phases. In Maldives, three waves were also reported to arrive between 09:00 and 09:30 local time. Maximum water level was only $h \sim 3 \mathrm{~m}$ in Laamu Atoll, which is interpreted by the wave amplitude damping by the coral reef to the east of the island complex as well as to that the tsunami did not arrived at high tide time. Damage was observed in several islands of Maldives but this was minimal as compared to the heavy destruction observed in Sri Lanka. About 25 Greek eyewitnesses, who happened to experience the tsunami attack in Padong and Blue Lagoon Port of Phuket island as well as in Maya Bay, Phi-Phi islands, Thailand, were interviewed on the basis of a standard questionnaire. The first sea motion was a retreat of at least $100 \mathrm{~m}$. Then, two main waves arrived, the first being the strong one occurring at about 09:55-10:05 local time, with $h \sim 6 \mathrm{~m}$ in Padong causing significant destruction and human victims. The collected information clearly indicates that the tsunami propagated as the leading crest wave to the west side, e.g. in Sri Lanka and Maldives, and as the leading trough wave to the east, e.g. in Thailand.
\end{abstract}

Key words: Sumatra earthquake, Indian Ocean tsunami, field observations, eyewitness accounts, Sri Lanka, Maldives Is., Thailand.

\section{Introduction}

The big earthquake (Mw 9.3) of 26 December 2004, 00:58:53 UTC (07:59 local time at the epicenter), which ruptured large part of the Indonesian and Andaman-Nicobar island arcs (Fig. 1), generated a large tsunami that spread out all over the Indian Ocean causing heavy destruction and more than 200,000 victims in hundreds of local communities in 11 countries. The collection of tsunami related observations in post-event field-surveys is of great importance for understanding not only the vulnerability parameters that favoured such a massive catastrophe but also the physical properties of the tsunamigenic source and the

Copyright (c) The Society of Geomagnetism and Earth, Planetary and Space Sciences (SGEPSS); The Seismological Society of Japan; The Volcanological Society of Japan; The Geodetic Society of Japan; The Japanese Society for Planetary Sciences; TERRAPUB tsunami waves. Because of the extremely large area affected by the tsunami, post-event field-surveys were organized by many scientific groups from different parts of the world (Papadopoulos and Satake, 2005).

In this paper, which is a full version of preliminary conference presentation (Papadopoulos et al., 2005), we present a set of observations made and measurements taken during tsunami post-event field-surveys as well as a collection of eyewitnesses accounts. Post-event field surveys were conducted in Sri Lanka from 8 to 14 January 2005 and in Maldives islands (Fig. 1) from 14 to 16 January 2005. At the same time tens of local people were interviewed and information about the physical features and the impact of the tsunami was collected. In addition to this, during January 2005 Greek eyewitnesses who happened to experience personally the tsunami attack in Phuket and Phi-Phi islands of 


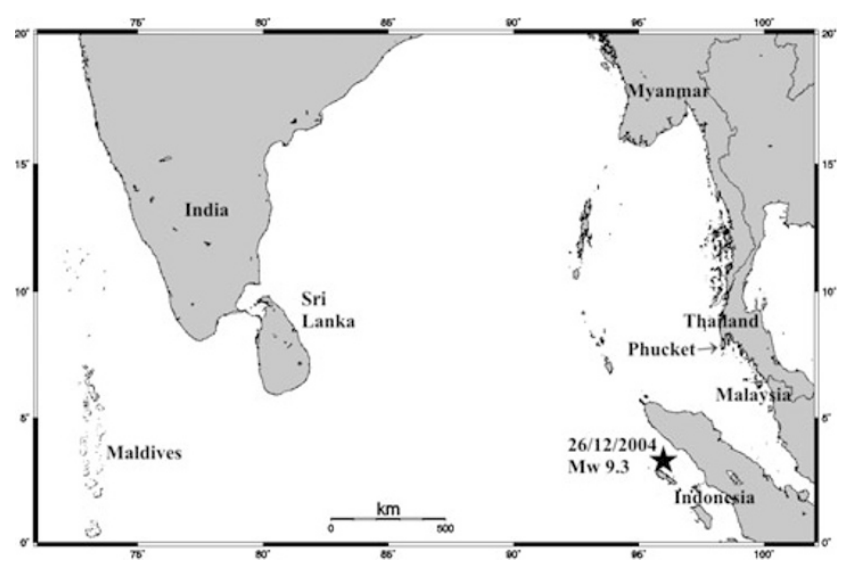

Fig. 1. The epicenter (star) of the big Sumatra earthquake of 26 December 2004 and the regions of Thailand, Sri Lanka and Maldives studied in the present paper.

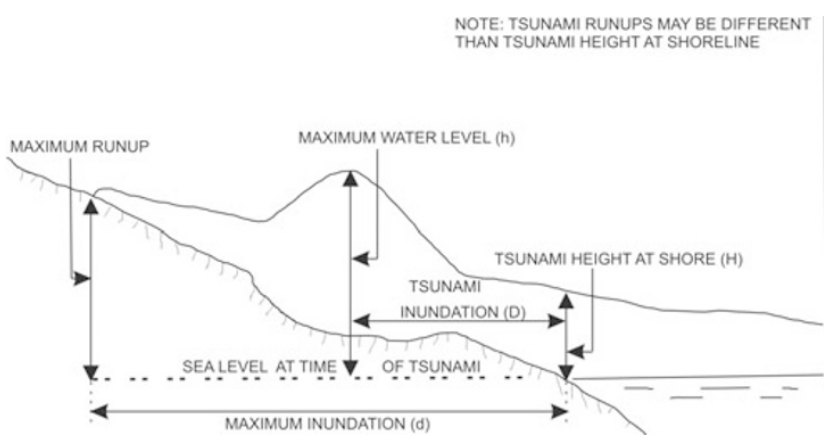

Fig. 2. Terminology for tsunami field markings (after IOC, 1998, with slight modification).

Thailand (Fig. 1) were interviewed and their accounts were collected and evaluated on the basis of a standard questionnaire. Finally, in the light of the observations accumulated we evaluate and interpret the variable destruction caused in connection to several physical and anthropogenic factors that control the tsunami risk in various coastal sites.

\section{Methodology}

\subsection{Terminology}

We use terms like "maximum water level, $h$ ", "tsunami height at shore, $H$ " and "maximum inundation or maximum horizontal intrusion, $d$ " as they were suggested by IOC (1998) and are explained in Fig. 2. In addition, we use the term "inundation, $D$ ", to describe the distance from shore where maximum water level was measured. Maximum water level, $h$, is not always identical with tsunami height at shore, $H$. One may assume that $H \sim h$ when $D$ is small, say $D<50 \mathrm{~m}$.

\subsection{Field observations and measurements}

In Sri Lanka, situated at epicentral distance of $\sim 1600 \mathrm{~km}$, the field investigation was extended along the southwest, south and east coasts (Fig. 3). In the west coast, field investigation was performed south of the capital city Colombo because north of the city the tsunami impact was minimal as reported by local people. In the southeast segment of coast, no observations were made from Hambantota to Pottuvill because this area was unaccessible due to road con-

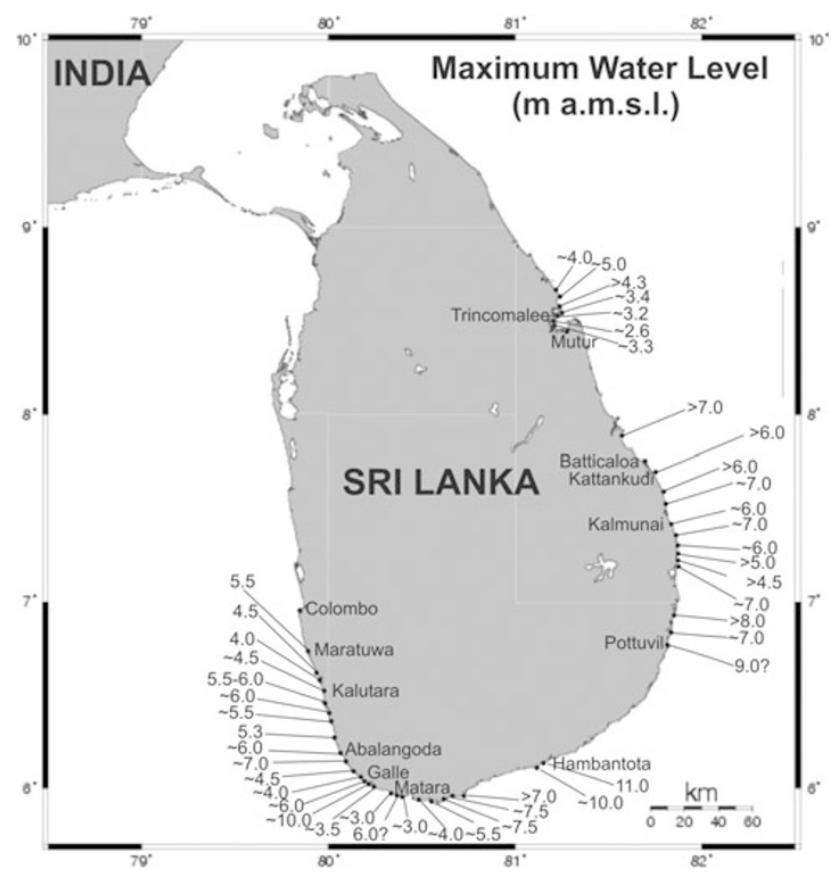

Fig. 3. Geographical distribution of the maximum water level, $h$ (in $\mathrm{m}$ ), measured in Sri Lanka.

ditions. For the same reason only very few measurements were taken in the northeast coast to the north of Trincomalee. In Maldives, situated at epicentral distance of $\sim 2500$ $\mathrm{km}$, islands of the North Malé Atoll, the South Malé Atoll and the Laamu Atoll were investigated.

In Sri Lanka and Maldives the maximum water level, $h$, as well as the inundation, $D$, were measured in several tens of spots from characteristic marks or traces left behind by the tsunami. On the other hand, we were able to reliably estimate the maximum horizontal intrusion, $d$, for a relatively small number of observation points. However, it is obvious that $D$ measured in a particular spot signifies the minimum value of $d$ in the spot.

The spots examined were located by hand GPS devices whereas distance measurements were taken by optical theodolite. The most common of the marks used to determine the maximum water level included sea sand or mud (Fig. 4) and water traces left on walls (Fig. 5), small objects trapped on trees and in window nets, damage caused in buildings and other structures (Fig. 6), fishing boats and other vessels that moved ashore by the wave, soil erosion (Figs. 7 and 8), and razing of vegetation caused by the tsunami action. In most of the investigated locations field observations and measurements were cross-checked after interviewing with local people. Reports of local people were of value for the estimation of the parameters $h, D$ and $d$, as well as of the number of main waves observed and the time of their incidence.

The values of $h$ estimated in the field were corrected for tide on the basis of the tide datum calculated for the Indian Ocean by the tsunami team of the Earthquake Research Institute, University of Tokyo (http://www.eri.u-tokyo.ac.jp/ namegaya/sumatera/tide/index). Therefore, the values of $h$ finally adopted are referred to above the mean sea level 


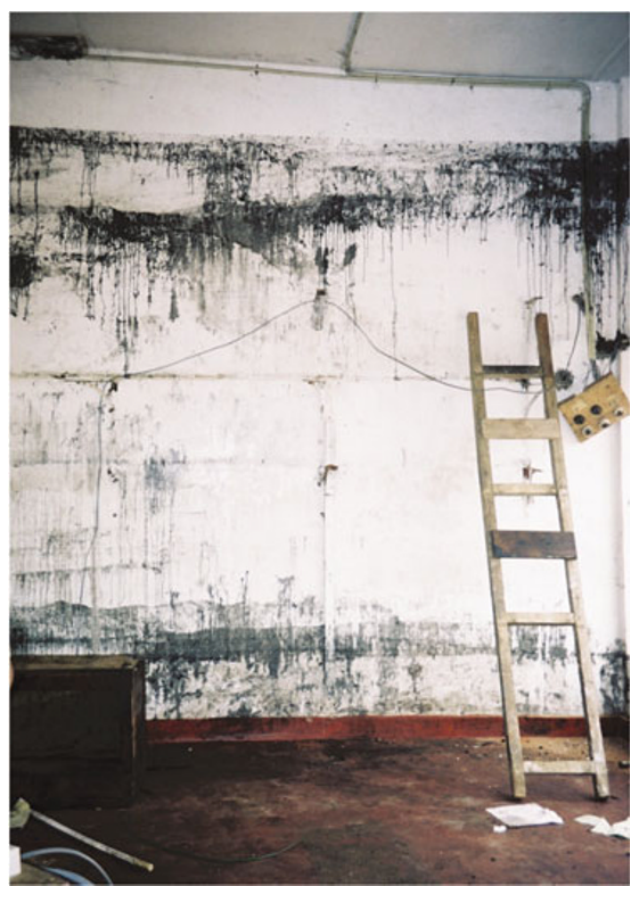

Fig. 4. Characteristic indoor sea sand mark left behind by the tsunami in the coastal zone of downtown Hambantota, south Sri Lanka. This is one of the locations where the maximum water level of $h \sim 11 \mathrm{~m}$ was measured.

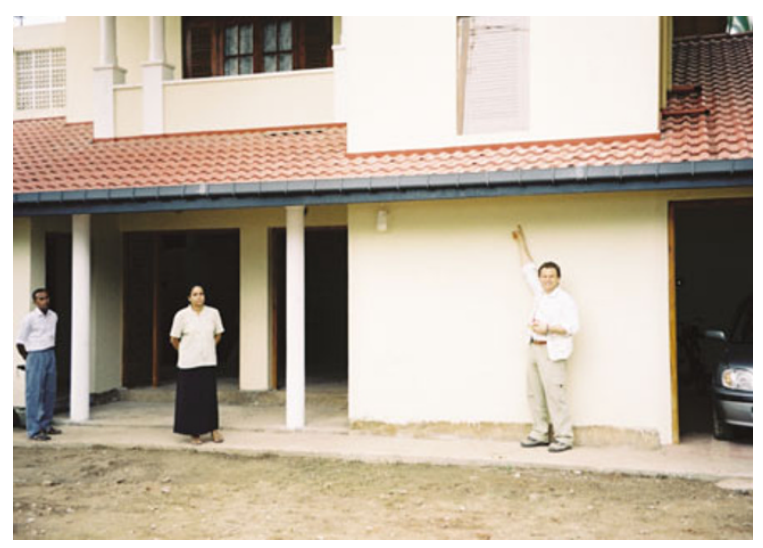

Fig. 5. Two-storey RC house that resisted very well the tsunami attack at distance of $\sim 80 \mathrm{~m}$ from the shoreline of Paralyia, southwest Sri Lanka. Only little damage was caused in doors and windows. Water mark was left on wall.

(a.m.s.l.) at the time of tsunami occurrence. Time is reported in UTC unless otherwise indicated.

\subsection{Eyewitnesses accounts}

Tsunami eyewitnesses were approached in Sri Lanka and Maldives Is. during the post-event field investigations. In addition, eyewitnesses accounts were collected in Greece by interviewing with Greek individuals who experienced the tsunami in the Phucket and Phi-Phi islands of Thailand, located at epicentral distance of $\sim 600 \mathrm{~km}$ (Fig. 1). The eyewitnesses were requested to respond to a standard questionnaire shown in Appendix. In Sri Lanka, at all the observation points where we performed field measurements, eyewitnesses accounts were collected with the help of our local driver who is fluent in both Sinhala and Tamil languages as

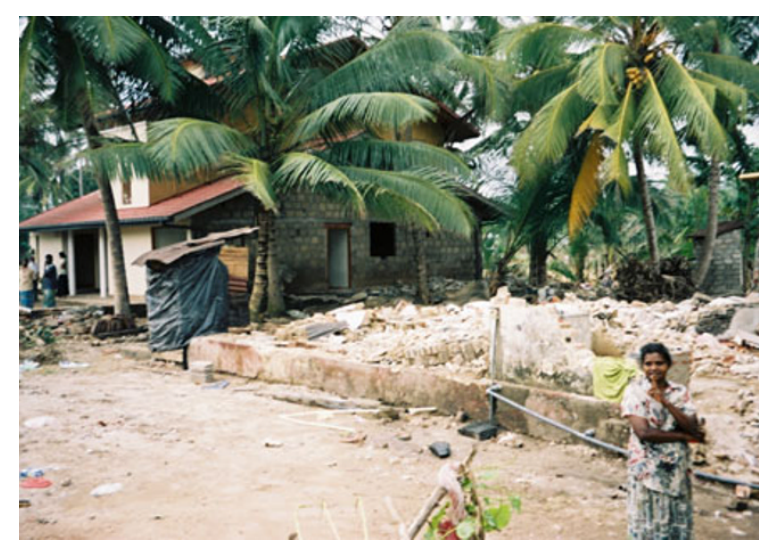

Fig. 6. Non-RC brick-work house completely demolished by the tsunami in Paralyia, southwest Sri Lanka. In the left-hand side the RC house (Fig. 5) makes strong contrast.

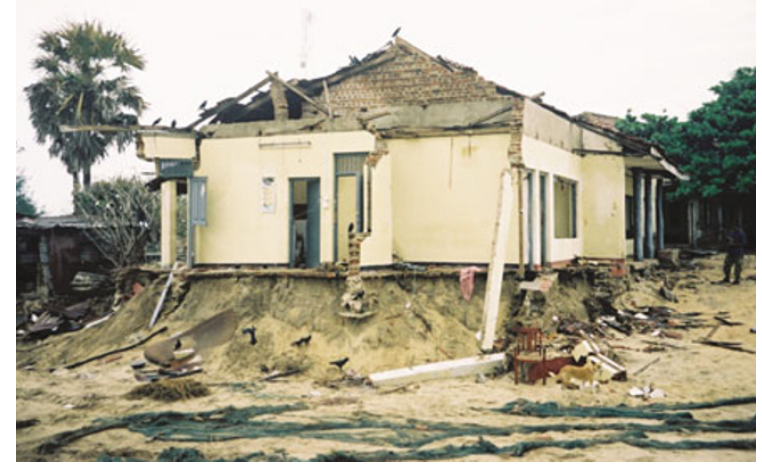

Fig. 7. The soil erosional action of the tsunami caused the sea-facing side of the non-RC building to collapse $(\sim 120 \mathrm{~m}$ from beach, near Karativu, east Sri Lanka).

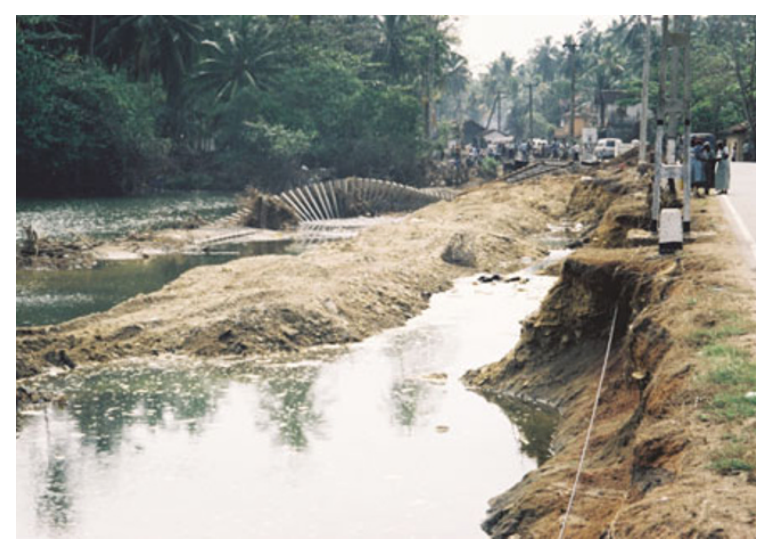

Fig. 8. Complete failure of railway due to lateral spreading and collapse of its embankment caused by the soil erosional action of the tsunami (Abalangoda, southwest Sri Lanka). The tsunami wave moved from the right-hand side to the left-hand side of the picture.

well as in English. In Maldives, the communication was made in English. In Sri Lanka and Maldives the pattern of the above mentioned questionnaire was followed.

The method for interviewing with eyewitnesses either in the field or in Greece was based on two basic principles. First, every eyewitness was approached independently from 
Table 1. Summary of field observations made and measurements taken in Sri Lanka. Key: $h=$ maximum water level, $D=$ effective inundation.

\begin{tabular}{|c|c|c|c|c|c|c|c|}
\hline \multirow{3}{*}{$\mathrm{c} / \mathrm{n}$} & \multirow{3}{*}{ Location } & \multicolumn{2}{|c|}{ Latitude } & \multicolumn{2}{|c|}{ Longitude } & \multirow{3}{*}{$\begin{array}{c}h(\mathrm{~m}) \\
\text { a.m.s.l. }\end{array}$} & \multirow{3}{*}{$D(\mathrm{~m})$} \\
\hline & & degr. & $\min$. & degr. & $\min$. & & \\
\hline & & & & & & & \\
\hline 1 & Maratuwa & 6 & 44.875 & 79 & 53.387 & 5.5 & 70 \\
\hline 2 & Wadduwa Resort & 6 & 40.675 & 79 & 55.245 & 4.5 & 120 \\
\hline 3 & Kalutara North & 6 & 36.36 & 79 & 56.953 & 4 & 80 \\
\hline 4 & Katukurunda (Kalutara S.) & 6 & 33.933 & 79 & 57.071 & ca. 4.5 & 120 \\
\hline 5 & Paiyagala & 6 & 31.903 & 79 & 58.651 & $5.5-6.0$ & \\
\hline 6 & Berawala & 6 & 29.178 & 79 & 59.003 & ca. 6.0 & \\
\hline 7 & Bentota North & 6 & 25.448 & 79 & 59.721 & 5.5 & 130 \\
\hline 8 & Balapitiya beach & 6 & 16.422 & 80 & 2.149 & 5.3 & 50 \\
\hline 9 & Abalangoda & 6 & 14.742 & 80 & 2.818 & ca. 6.0 & \\
\hline 10 & Seenigama & 6 & 12.034 & 80 & 3.852 & ca. 7.0 & \\
\hline 11 & Rathgama/ Dodanduwa & 6 & 5.15 & 80 & 8.763 & 4.5 & 50 \\
\hline 12 & Galle north & 6 & 2.853 & 80 & 11.312 & 4 & \\
\hline 13 & Galle Center & 6 & 1.512 & 80 & 12.975 & 6 & 50 \\
\hline 14 & Galle Fort & 6 & 2.179 & 80 & 13.342 & ca. 10 & 0 \\
\hline 15 & Punawatunna & 6 & 1.557 & 80 & 14.745 & ca. 3.5 & \\
\hline 16 & Jayaduwa/ Habaraduwa & 5 & 59.63 & 80 & 18.51 & ca. 3.0 & \\
\hline 17 & Koggala & 5 & 59.045 & 80 & 19.942 & 6.0 & 500 \\
\hline 18 & Ahangama & 5 & 58.417 & 80 & 21.643 & ca. 3.0 & 50 \\
\hline 19 & Weligama/ Kamburugamu & 5 & 58.346 & 80 & 25.881 & ca. 4.0 & \\
\hline 20 & & 5 & 56.467 & 80 & 29.652 & ca. 5.5 & \\
\hline 21 & Matara/Gandara & 5 & 55.888 & 80 & 34.98 & ca. 7.5 & \\
\hline 22 & Eva Hotel & & & & & ca. 7.5 & \\
\hline 23 & Tangalle & & & & & $>7.0$ & \\
\hline 24 & Hambantota & 6 & 7.081 & 81 & 5.853 & ca. 10 & \\
\hline 25 & Hambantota & 6 & 7.49 & 81 & 7.577 & ca. 11 & \\
\hline 26 & Pottuvil & 6 & 52.522 & 81 & 50.658 & 9.0 & 150 \\
\hline 27 & Pottuvil & 6 & 52.45 & 81 & 50.636 & 7 & 230 \\
\hline 28 & Komari & 6 & 58.57 & 81 & 51.818 & $>8.0$ & \\
\hline 29 & Akkaraipattu & 7 & 12.569 & 81 & 51.59 & $>4.5$ & 200 \\
\hline 30 & Sinnamuhattuvaram & 7 & 10.389 & 81 & 51.595 & ca. 7.0 & 120 \\
\hline 31 & Addacachchena & 7 & 14.999 & 81 & 51.818 & $>5.0$ & 100 \\
\hline 32 & Oluvil & 7 & 17.336 & 81 & 51.965 & 6 & 100 \\
\hline 33 & Karativu & 7 & 23.048 & 81 & 50.853 & ca 7.0 & \\
\hline 34 & Kalmunai & & & & & 6 & 35 \\
\hline 35 & Kaluwanchikudi & 7 & 31.253 & 81 & 48.335 & 7 & 100 \\
\hline 36 & Cheddipalayam & 7 & 35.019 & 81 & 47.4 & $>6.0$ & \\
\hline 37 & Kallady & 7 & 43.429 & 81 & 42.853 & $>6.0$ & \\
\hline 38 & Kalkudah & 7 & 55.138 & 81 & 33.963 & $>7.0$ & 500 \\
\hline 39 & China Bay & 8 & 34.299 & 81 & 11.531 & 3.2 & 10 \\
\hline 40 & China Bay Ferry & 8 & 30.747 & 81 & 11.472 & ca. 3.3 & \\
\hline 41 & Trincomalee & 8 & 34.565 & 81 & 14.207 & ca. 3.4 & 30 \\
\hline 42 & Uppuveli & 8 & 36.954 & 81 & 13.133 & $>4.3$ & \\
\hline 43 & Irrakkakandi & 8 & 43.517 & 81 & 10.616 & ca. 4.0 & 100 \\
\hline 44 & Nilaveli & 8 & 40.597 & 81 & 12.189 & ca. 5.0 & \\
\hline
\end{tabular}

others with the aim to avoid confusion and personal influences. However, in Sri Lanka local circumstances were not always favourable to follow this practice given that often we were approached by tens of local people who were ready to talk about their personal tsunami history. Second, a systematic effort was made to cross-check several pieces of information with as many individuals as possible.

\section{Observations and Measurements \\ 3.1 Sri Lanka}

The observations made and measurements taken during the field investigations are summarized in Table 1. In Sri
Lanka, maximum water level was estimated to range from $2.6 \mathrm{~m}$ to $11 \mathrm{~m}$ (Fig. 3). The highest values measured are concentrated in the south part of the island from Ambalangoda in southwest to Pottuvill in southeast and particularly in Hambantota $(h=11 \mathrm{~m})$ and near Galle $(h \sim 10 \mathrm{~m})$ (Fig. 3). Values of $h$ ranging from $4.5 \mathrm{~m}$ to $9 \mathrm{~m}$ were measured in the east cost from Pottuvill to around Batticaloa. Sets of relatively low values were observed in the northeast part around Trincomalee ( $h$ ranges from 2.6 to $5.0 \mathrm{~m}$ ) and in the west coast from Moratuwa to Ambalangoda ( $h$ ranges from $4.0 \mathrm{~m}$ to $5.0 \mathrm{~m}$ ). The inundation, $D$, ranged from about $50 \mathrm{~m}$ to $500 \mathrm{~m}$, while maximum inundation, $d$, is equal to at 


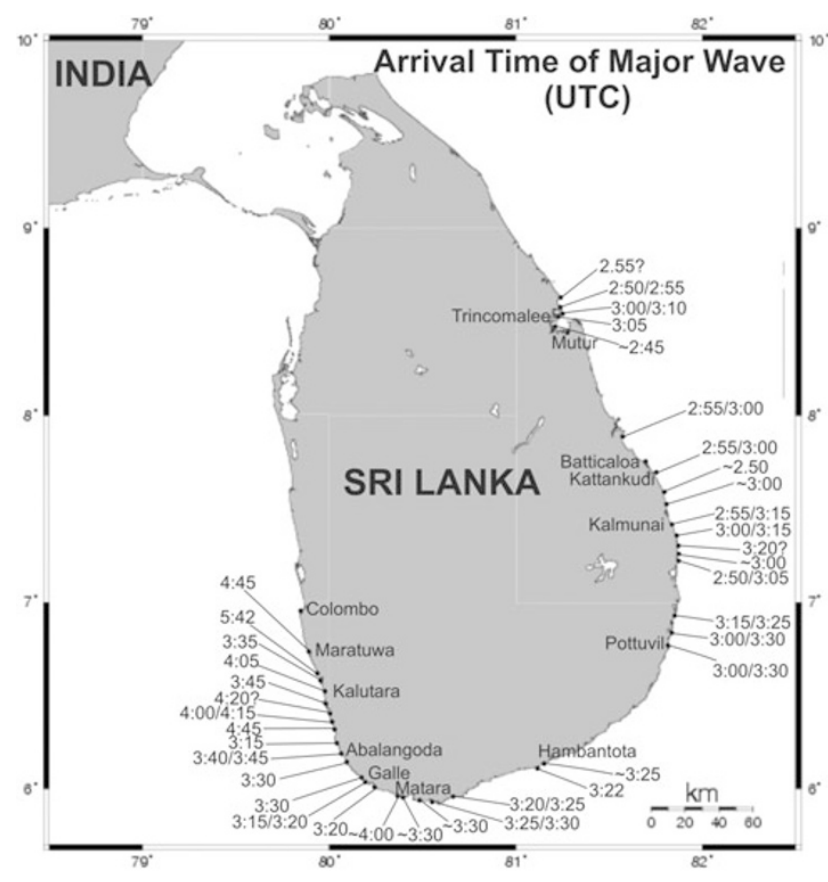

Fig. 9. Geographical distribution of the times of the major tsunami wave arrival in Sri Lanka according to eyewitnesses accounts.

least $D$. An extreme case of $d$ was observed in Hambantota where inundation of the order of $2 \mathrm{~km}$ was estimated.

Eyewitness accounts are divergent as for the number of waves observed. This number ranges between one and three depending on the observation time and place as well as on each observer's personal judgment. However, most of the eyewitnesses described the tsunami flooding as a series of three main waves. The first wave was described only as a silent sea level rise with maximum water level not exceeding $1.5 \mathrm{~m}$ and inundation of no more than $d \sim 150$ $\mathrm{m}$. However, the second wave as a rule was described as the most powerful and destructive one, while the size of the third wave was likely intermediate as compared to the small and large sizes of the first and the second waves, respectively. Accoording to eyewitnesses, after the occurrence of the leading wave phase and before the arrival of the second strong wave a significant sea retreat was observed. As an example, in Hambantota local people estimated the sea retreat to be of the order of $500 \mathrm{~m}$. Sea retreat usually was described to occur after the second wave and before the third one.

Several inhabitants reported that the inter-arrival times of the three waves ranged between 5 and $15 \mathrm{~min}$. However, most people were confused because the leading wave phase passed unnoticed while the second wave caused them to run to higher ground so that the arrival time of the third wave again escaped their notice. The arrival times reported for the most powerful wave are illustrated in Fig. 9. In some instances the confusion mentioned above is obvious. To calibrate against confusion we used a picture published on 13 January 2005 by the newspaper "Gulf Today" showing a public clock in a village near Galle that stopped at 09:25:30 local time (03:25:30 UTC) because of the tsunami attack. We assume that the clock stand was attacked by the second

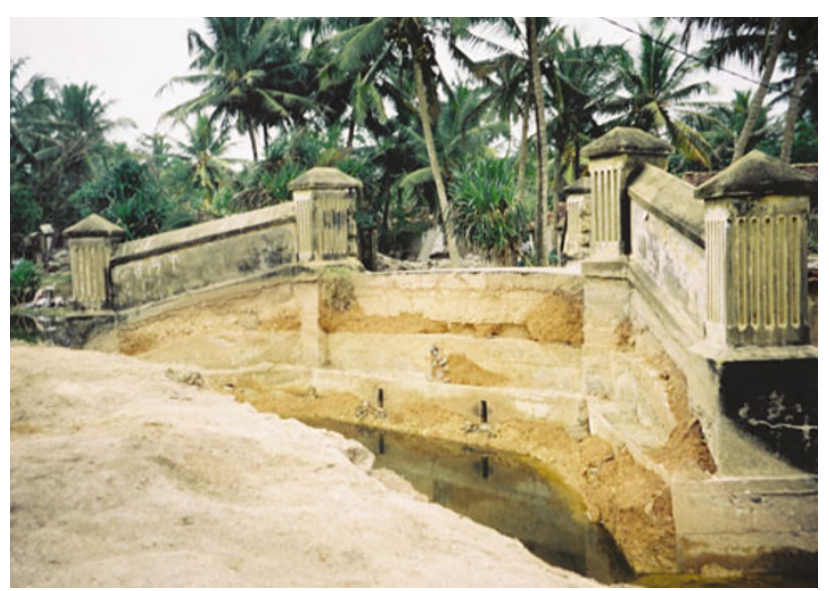

Fig. 10. The soil erosional action along with the force of the hydrodynamic flow of the tsunami caused collapse of one side of bridge (North Kalutara, southwest Sri Lanka).

wave arrival.

After this calibration, we assume that in the east coast the strong wave arrived between 03:00 and 03:15. Some reports about late arrivals $(\sim 03: 30)$ possibly describe the third wave. In the southern zone of the island the reported arrival of the second wave ranges between 03:15 and 03:30 which is consistent with the calibrated time. In the southwest side between Moratuwa and near to the north of Ambalangoda the confusion becomes more strong. Arrivals on 03:35 or 03:45 very possibly correspond to the second strong wave. However, delayed wave phases ranging between 04:00 and 05:42 may describe the third wave reported. Liu et al. (2005) suggested that the late wave phases may be reflection from the coast of India or from Maldives. An alternative is that they may represent late wave phases generated during the refraction of the leading waves around the southern tip of Sri Lanka.

The tsunami wave caused destruction of buildings and infrastructure, like railways and bridges, and substantial loss of life. A total death toll of at least 20,000 has been estimated for all of Sri Lanka. The tsunami caused destruction directly by the action of its hydrodynamic flow and indirectly by extensive soil erosion. The most critical parameter of the hydrodynamic flow has been the value of $h$, that is of the maximum water level. In fact, the most extensive disaster was noted in the south part of the island (e.g. Galle, Hambantota) where the maximum values of $h$ were measured. In Hambantota alone, at least 2,000 people died. Destruction was also caused in other coastal zones with significant values of $h$, as in the southwest (e.g. Kalutara, Paralyia), southeast (Pottuvil) and east (Batticaloa, Trincomalle) sides of the island. However, the disaster is attributed not only to the significant wave heights but also to the increased vulnerability of the coastal communities. The high population density along with the lack of tsunami awareness prevailing in most coastal communities of Sri Lanka increased drastically their vulnerability to the tsunami attack. In addition, non reinforced-concrete (nRC) rural buildings, like brick-works, proved extremely vulnerable to the tsunami force. On the contrary, RC structures suffered much less. 


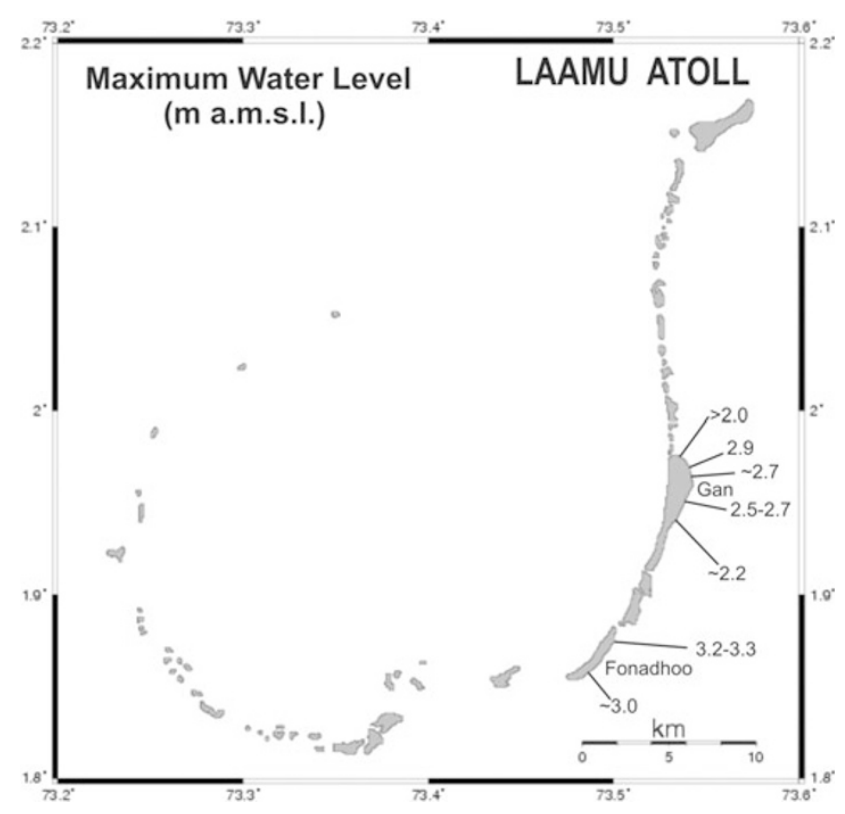

Fig. 11. Geographical distribution of the maximum water level, $h$ (in $\mathrm{m}$ ), measured in Laamu Atoll, Maldives.

Figures 5 and 6 show a characteristic example of one $\mathrm{nRC}$ and one RC building situated at exactly the same spot of observation at a distance of about $80 \mathrm{~m}$ from the shoreline of Paralyia, southwest Sri Lanka: the nRC building was completely demolished by the tsunami, while the RC one resisted very well and only minor damage was noted on it.

Inundation $d$ is very sensitive to natural or artificial coastal geomorphology parameters and this proved to be of critical importance for the variable extent of disaster caused even in locations situated very close to each other. As an example, in Galle, south Sri Lanka, the $6 \mathrm{~m}$-high wall of the 17th century Portuguese-Dutch fort protected part of the city. However, the part of the city which is not protected by this wall was seriously damaged. In other locations, the existence of sand dunes along the coastal zones contributed to the significant decrease of inundation $d$ with respect to the values of $d$ observed in nearby locations unprotected by sand dunes. For example, in particular spots of observations in Bentota sand dunes were removed by local residents and this resulted to the increase of both inundation and destruction.

The tsunami erosional action in soil was a factor of destruction in buildings and infrastructure. Buildings with eroded foundations typically tilted, and because of this were damaged or even were collapsed (Fig. 7). Along railways erosion caused the embankement either to collapse or to spread laterally (Fig. 8). Because of this the railway system along the coastal zones hit by the tsunami was destroyed in many localities. Tens of bridges were also destroyed because either of the hydrodynamic force of the wave or its erosional action at the base of the bridge or both (Fig. 10).

\subsection{Maldives Is.}

In Maldives post-event field investigation was conducted on North Malé Atoll, South Malé Atoll and Laamu (Haddummati) Atoll (Table 2). The maximum water level was estimated to range from $1.4 \mathrm{~m}$ to $3.3 \mathrm{~m}$ a.m.s.l. (Figs. 11 and

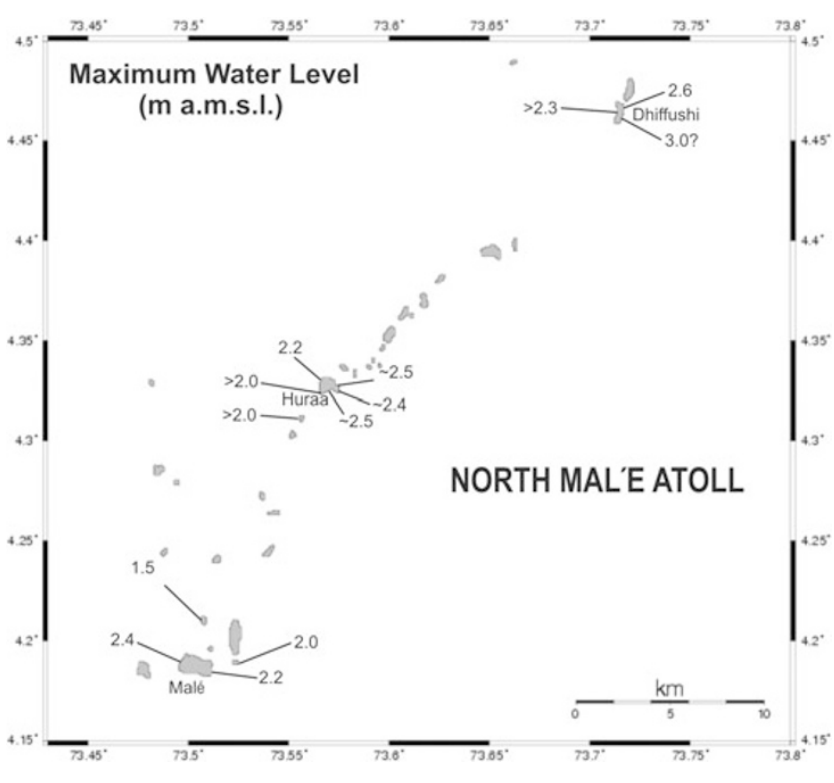

Fig. 12. Geographical distribution of the maximum water level, $h$ (in $\mathrm{m}$ ), measured in North Malé Atoll, Maldives.

12). The highest values of 3.2 to $3.3 \mathrm{~m}$ were measured in the ocean side of Fonadhoo islet of Laamu Atoll In this area rural buildings were heavily damaged; 22 persons died and another three are missing. However, in the atoll side maximum water level did not exceeded $2 \mathrm{~m}$. The inundation, $D$, usually ranged from about $10 \mathrm{~m}$ to $100 \mathrm{~m}$. However, on North and South Malé Atolls, $h$ ranged from 1.3 to 2.5 m (Fig. 13), while inundation occurred up to $d \sim 300 \mathrm{~m}$. As in Sri Lanka, most of the eyewitnesses reported that the tsunami wave consisted of three main tidal phases. The first was a slight sea rise and reported to occur in the time range from 04:00 to 04:20 (09:00 to 09:20 local) depending on the observation time and point and the observer's personal judgment. The second wave was the most powerful and reportedly arrived in the time range from 04:25 to 04:30. The example of wave arrival reported in Malé island is shown in Fig. 14. Local people agreed on that the sea became calm between 05:30 and 06:00.

In Maldives only about 80 people died, which is quite different from what happened in Sri Lanka. Two critical parameters that may explain the drastic decrease in the impact of the tsunami wave in Maldives are the reduced strength of hydrodynamic flow and the reduced vulnerability of local communities. In Maldives the maximum water level was no more than about $3 \mathrm{~m}$ which implies strength of hydrodynamic flow much less with respect to that which acted in Sri Lanka. The relatively low water level is interpreted to have been caused by the wave amplitude damping caused by the coral reef situated to the east of the island complex and because the tsunami did not arrive at high tide. Another explanation is that the tsunami might be amplified by the sea bottom topography near Sri Lanka, while that was not amplified near the Maldives because of the steep coast outside the atoll. As for the vulnerability of the coastal communities one may expect that it would be high in Maldives due to the nearly flat ground elevation. However, this is not the case and vulnerabiltiy is drastically reduced in Maldives. In fact, 
Table 2. Summary of field observations made and measurements taken in Maldives. Key: $h=$ maximum water level, $D=$ effective inundation.

\begin{tabular}{|c|c|c|c|c|c|c|c|}
\hline \multirow{3}{*}{$\mathrm{c} / \mathrm{n}$} & \multirow{3}{*}{ Location } & \multicolumn{2}{|c|}{ Latitude } & \multicolumn{2}{|c|}{ Longitude } & \multirow{3}{*}{$\begin{array}{c}h(\mathrm{~m}) \\
\text { a.m.s.l. }\end{array}$} & \multirow{3}{*}{$D(\mathrm{~m})$} \\
\hline & & degr. & $\min$. & degr. & $\min$. & & \\
\hline & & & & & & & \\
\hline 1 & North Malé Atoll, Huhule Is. & 4 & 11.672 & 73 & 31.539 & 2 & 20 \\
\hline 2 & North Malé Atoll, Malé Is. & 4 & 10.325 & 73 & 30.141 & 2.4 & 30 from harbour \\
\hline 3 & North Malé Atoll, Malé Is. & & & & & & 15 from harbour, 40 from sea \\
\hline 4 & North Malé Atoll, Malé Is. & 4 & 10.165 & 73 & 30.349 & 1.8 & 15 \\
\hline 5 & North Malé Atoll, Malé Is. & 4 & 10.182 & 73 & 30.803 & 1.6 & 10 \\
\hline 6 & North Malé Atoll, Malé Is. & 4 & 10.214 & 73 & 31.012 & $>1.7$ & $20+20$ of rocky shallow water \\
\hline 7 & North Malé Atoll, Malé Is. & 4 & 10.423 & 73 & 31.073 & 2.2 & $70+20$ of rocky shallow water \\
\hline 8 & North Malé Atoll, Malé Is. & 4 & 10.72 & 73 & 30.85 & 1.3 & 10 from internal jetty \\
\hline 9 & North Malé Atoll, Malé Is. & & & & & 1.4 & 10 from internal jetty \\
\hline 10 & North Malé Atoll, Malé Is. & 4 & 10.812 & 73 & 30.578 & 1.7 & $\begin{array}{l}50 \text { from internal jetty, but } \\
250 \text { along street }\end{array}$ \\
\hline 11 & South Malé Atoll,Embudhu Finothu & & & & & 1.7 & \\
\hline 12 & South Malé Atoll, Embudhu Finothu & & & & & 2.8 & 0 \\
\hline 13 & Laamu Atoll, Fonadhoo Is. & 1 & 49.944 & 73 & 30.2 & $3.2-3.3$ & ca. 50 \\
\hline 14 & Laamu Atoll, Fonadhoo Is. & 1 & 49.452 & 73 & 29.704 & ca. 3? (night) & ca. 30 \\
\hline 15 & Laamu Atoll, Fonadhoo Is. & 1 & 49.478 & 73 & 29.712 & $<3.0$ & ca. 50 \\
\hline 16 & Laamu Atoll, Gan Is. & 1 & 56.54 & 73 & 32.65 & ca. $2(?)$ & \\
\hline 17 & Laamu Atoll, Gan Is. & 1 & 55.941 & 73 & 33.114 & 2.9 & 30 \\
\hline 18 & Laamu Atoll, Gan Is. & 1 & 55.394 & 73 & 33.073 & ca. 2.7 & $70-80$ \\
\hline 19 & Laamu Atoll, Gan Is. & 1 & 55.376 & 73 & 32.988 & 2.7 & 10 \\
\hline 20 & Laamu Atoll, Gan Is. & & & & & ca. 2.2 & 100 \\
\hline 21 & North Malé Atoll, Dhiffushi Is. & 4 & 26.609 & 73 & 42.873 & 3 & \\
\hline 22 & North Malé Atoll, Dhiffushi Is. & 4 & 26.595 & 73 & 42.873 & ca. 2.6 & $60-70$ \\
\hline 23 & North Malé Atoll, Dhiffushi Is. & 4 & 26.635 & 73 & 42.819 & $>2.3$ & 15 \\
\hline 24 & North Malé Atoll, Huraa Is. & 4 & 19.995 & 73 & 35.965 & 2.4 & 30 \\
\hline 25 & North Malé Atoll, Huraa Is. & 4 & 19.94 & 73 & 36.083 & & 50 \\
\hline 26 & North Malé Atoll, Huraa Is. & 4 & 20.014 & 73 & 36.056 & 2.2 & \\
\hline 27 & North Malé Atoll, Kuda Huraa Is. & & & & & $>1.5$ & 0 \\
\hline 28 & Fish Factory & 4 & 14.951 & 73 & 32.206 & 1.5 & 10 \\
\hline
\end{tabular}

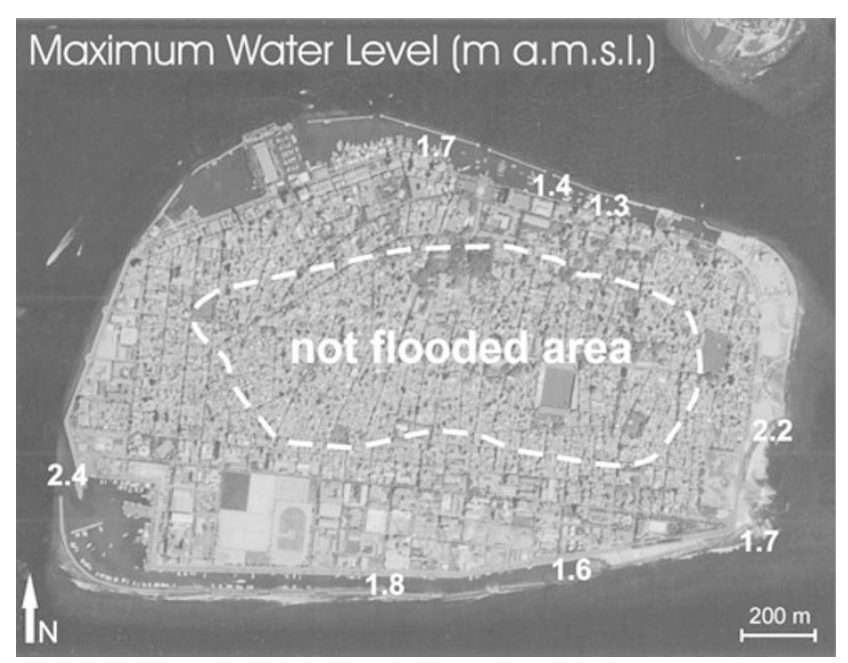

Fig. 13. Geographical distribution of the maximum water level, $h$ (in $\mathrm{m}$ ), measured in Malé island, North Malé Atoll, Maldives.

the low population density in Maldives makes a dramatic contrast with the high population density in Sri Lanka. In addition, infrastrure that dominates the coastal zones of Sri Lanka and proved highly vulnerable, like bridges and railways, do not meet in Maldives.

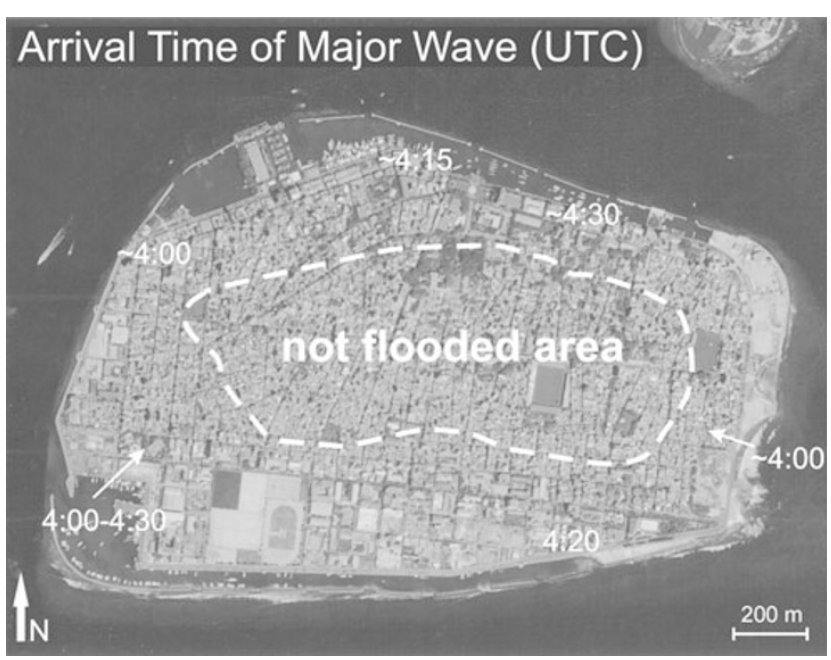

Fig. 14. Geographical distribution of the times of major tsunami wave arrival in Malé island, North Malé Atoll, Maldives, according to eyewitnesses accounts.

\subsection{Thailand}

About 25 individual Greeks who happened to be in Thailand for Christmas vacation responded to our questionnaire survey. Most of them experienced the tsunami in Patong beach, west side of Phucket island (Figs. 1 and 15). Three out of 25 were sailing from Boat Lagoon, east side of 


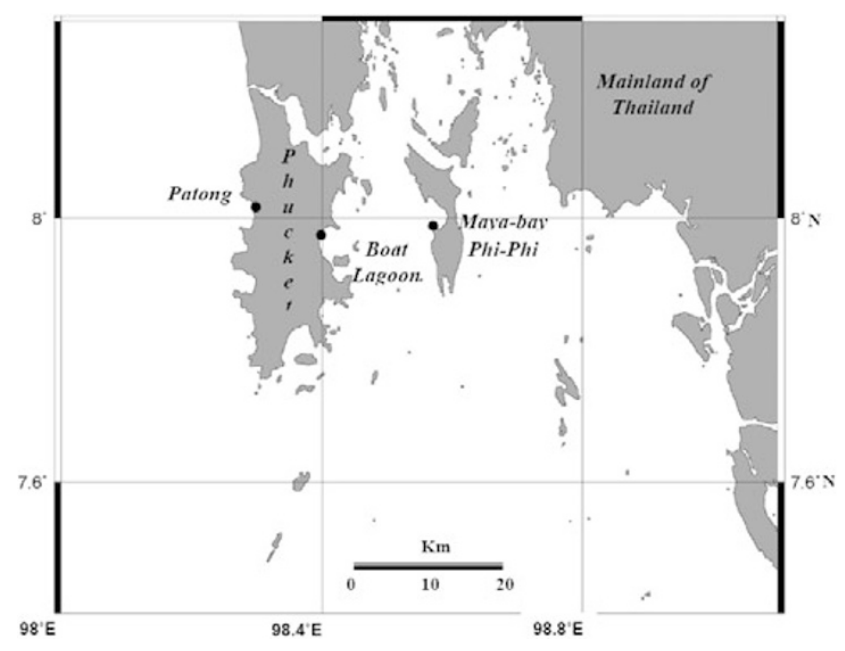

Fig. 15. Geography of the Thailand locations surveyed on the basis of eyewitnesses accounts.

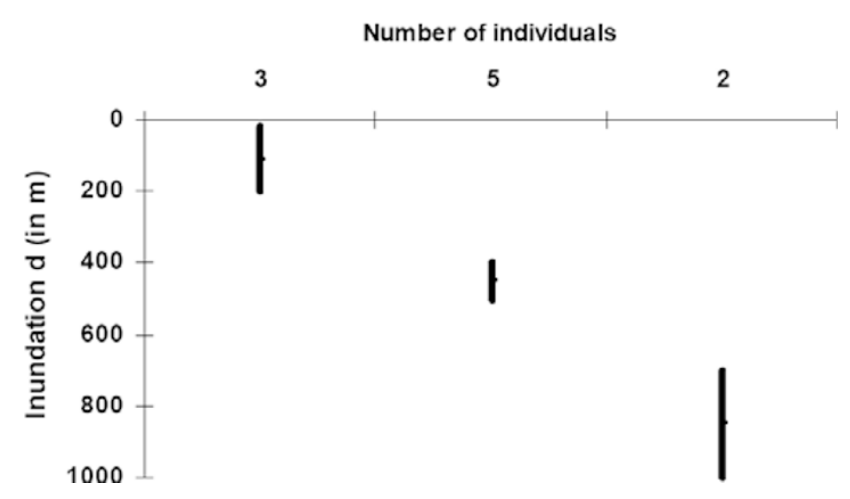

Fig. 16. Inundation, $d$, in Padong beach, Phucket island, Thailand, according to eyewitnesses accounts.

Phucket, to Maya Bay, Phi-Phi island (Fig. 15), and were able to describe what they observed in these places.

In Patong beach, most people observed at least two waves. It is likely that the leading wave described in both Sri Lanka and Maldives was not observed in Patong beach. What people said is that the first sea motion was a retreat of more than $100 \mathrm{~m}$. A few minutes later the strong wave arrived. Then, after another 5 or $10 \mathrm{~min}$. one more wave attacked but less violently than the first one. Nearly all the interviewed persons reported that the tsunami inundation in the Patong beach varied from $150 \mathrm{~m}$ to at least $750 \mathrm{~m}$ (Fig. 16). One eyewitness reported inundation of only 20 $\mathrm{m}$. As for the arrival time of the strong wave the eyewitnesses do not agree. However, most reports concentrated around 02:55 to 03:05 (09:55 to 10:05 local) which seems to be a reliable description (Fig. 17).

The tsunami caused several human victims and heavy damage in the coastal zone of Patong beach. Cars drifted away, crashed onto each other or collided with buildings. Wooden structures were destroyed, whereas masonry buildings were heavily damaged. In Boat Lagoon, the strong wave arrived around 03:10 and caused serious damage in the coastal zone where the local marina failed.

In Maya Bay, eyewitnesses reported that at around 02:55 the sea retreated for about $200 \mathrm{~m}$. A few minutes later a

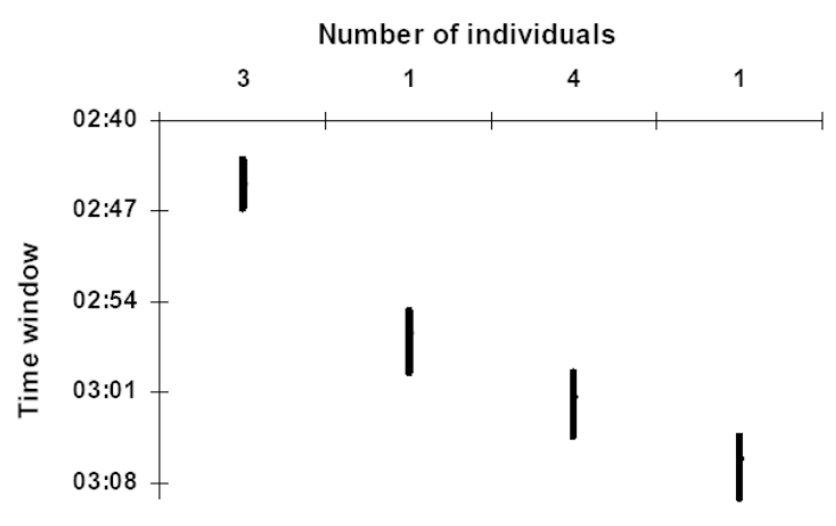

Fig. 17. Time windows (vertical bars) of reported tsunami occurrence in Padong beach, Phucket island, Thailand, according to eyewitnesses accounts.

strong wave arrived that inundated for about 200 to 300 meters. All bungalows and other small wooden houses were swept away and some human victims were noted. Eyewitnesses sailing from Boat Lagoon to Maya Bay on a 3,000 $\mathrm{kg}$ speed boat reported that around 03:15 strong turbulence hit the boat "along with strong strikes coming from all directions" and because of this sailing became extremely dangerous for several minutes.

\section{Concluding Remarks}

In Sri Lanka, maximum water level, $h$, was estimated to range from $2.6 \mathrm{~m}$ to $11 \mathrm{~m}$. The highest values were measured in Hambantota $(h=11 \mathrm{~m})$ and near Galle $(h \sim$ $10 \mathrm{~m}$ ) in the south part of the island. Values of $h$ ranging from $4.5 \mathrm{~m}$ to $9 \mathrm{~m}$ were measured in the east coast from Pottuvill to around Batticaloa. Relatively low values were observed in northeast around Trincomalee ( $h=2.6$ to 5.0 $\mathrm{m})$ and in the west coast from Moratuwa to Ambalangoda ( $h=4.0$ to $5.0 \mathrm{~m}$ ). The inundation, $D$, ranged from about $50 \mathrm{~m}$ to $500 \mathrm{~m}$, while maximum inundation, $d$, is equal to at least $D$. An extreme case of $d$ was observed in Hambantota ( $d \sim 2 \mathrm{~km}$ ). It seems that the tsunami flooding consisted of three main waves. The first was only a silent tide of $h \leq 1.5 \mathrm{~m}$ and inundation of no more than $d \sim 100$ $\mathrm{m}$. The second wave was described as the most powerful and destructive one, while the size of the third wave was likely intermediate. After the occurrence of the leading wave phase and before the arrival of the second strong wave a significant sea retreat was observed, like in Hambantota where local people estimated the sea retreat to be of the order of $500 \mathrm{~m}$. Sea retreat usually was also described to occur after the second wave and before the third one.

In the east coast it seems that the strong wave arrived between 03:00 and 03:15. Some reports about late arrivals ( 03:30) possibly describe the third wave. In the southern zone of the island the reported arrival of the second wave ranges between 03:15 and 03:30 but it is well documented that near Galle, southern part, the strong wave arrived at 03:25:30. In the southwest side between Moratuwa and near to the north of Ambalangoda, delayed, possibly reflection wave phases arrived between 04:00 and 05:42.

The tsunami wave caused heavy destruction in the population, the built environment and the infrastructure, like the 
railway system and bridges. A total death toll of at least 20,000 was estimated in the entire Sri Lanka. The tsunami caused heavy destruction directly by the action of its hydrodynamic flow and indirectly by the extensive soil erosion. The heaviest disaster was noted in the south part of the island where the maximum values of $h$ were measured, like in Galle and Hambantota. Therefore, $h$ has been the most critical parameter of the hydrodynamic flow. Only in Hambantota ( $h=11 \mathrm{~m}$ ) about 2,000 victims were counted. Heavy destruction was also caused in other coastal zones with significant values of $h$, like in the southwest (e.g. Kalutara, Paralyia), southeast (Pottuvil) and east (Batticaloa, Trincomalle) sides of the island. The tsunami erosional action in soil caused destruction in buildings and infrastructure. Other physical factors that contributed to the disaster include the effective or the maximum inundation of the wave and coastal geomorphology.

Anthropogenic factors contributed greatly to the disastrous effects of the tsunami. In fact, nRC buildings proved extremely vulnerable to the tsunami attack. On the contrary, $\mathrm{RC}$ structures suffered much less. The high population density along with the lack of tsunami awareness prevailing in most coastal communities of Sri Lanka increased drastically their vulnerability to the tsunami attack. In some instances, the artificial lowering or removal of sand dunes increased locally the community exposure to tsunami risk.

In Maldives, the North Malé Atoll, the South Malé Atoll and the Laamu Atoll were investigated. The maximum water level ranged between $1.4 \mathrm{~m}$ and $3.3 \mathrm{~m}$ a.m.s.l. The highest values of 3.2 to $3.3 \mathrm{~m}$ were measured in the ocean side of Fonadhoo islet of Laamu Atoll where rural buildings were heavily damaged; 22 persons died and another three are missing. In the atoll side, however, maximum water level did not exceeded $2 \mathrm{~m}$. The effective inundation, $D$, usually ranged from about $10 \mathrm{~m}$ to $100 \mathrm{~m}$. It seems that the tsunami wave consisted by three main tidal phases. The first was a slight sea rise occurring in the time range from 03:00 to $03: 20$. The second wave was the most powerful and reportedly arrived in the time range from 03:25 to $03: 30$. The sea became calm between 05:30 and 06:00.

The total number of victims caused by the tsunami is about 80 which makes an extremely different picture with respect to what happened in Sri Lanka. Two are the critical parameters that may explain the drastic difference in the impact of the tsunami wave: relatively low water level $(h \leq 3$ $\mathrm{m}$ ) and decreased vulnerability of the coastal communities. The relatively low water level is interpreted by the wave amplitude damping caused by the coral reef situated to the east of the island complex as well as to that the tsunami did not arrived at high tide time. According to Fujima et al. (2005), particularly in Male the seawall protected the city from worst tsunami impact.

In Thailand, in Patong beach, west side of Phucket island, in the Boat Lagoon Port, east side of Puchet, and in Maya Bay, Phi-Phi islands, eyewitnesses reported that the strong wave arrival occurred between 02:55 to 03:10. In Patong, the first sea motion was a retreat of more than $100 \mathrm{~m}$. A few minutes later the strong wave arrived. Then, after another 5 or $10 \mathrm{~min}$. one more wave attacked but less violently than the first one. The tsunami inundation in the Patong beach varied from $150 \mathrm{~m}$ to at least $750 \mathrm{~m}$. The tsunami caused several human victims and heavy damage in the coastal zone of Patong beach. In the Boat Lagoon Port the wave caused serious damage in the coastal zone. In Maya Bay, Phi-Phi islands, the first motion was a sea retreat for about $200 \mathrm{~m}$ that occurred around 02:55. A few minutes later the strong wave arrived causing few human victims and destruction to bungalows and wooden houses. The collected information clearly indicates that the tsunami propagated as the leading crest wave to the west side, e.g. in Sri Lanka and Maldives, and as the leading trough wave to the east, e.g. in Thailand.

Acknowledgments. The post-tsunami field survey was financially supported by the EU research project LEWIS (ENG1-CT2001-00055), the Institute of Geology, ETH, Zürich, and the newspaper "Eleftherotypia", Athens. We are thankful to Andrew Moore and to one anonymous reviewer for their valuable suggestions in order to improve the manuscript. Thanks are extended to Mr. Naushad, our unwearied car driver, who helped us a lot not only in driving but also in communicating with local people. We also thank Mr. Filios Stagos, correspondant in Sri Lanka of the Greek public TV channel NET, for the valuable information and advise he passed to us during the preparation of our field survey.

\section{Appendix.}

Questionnaire used to collect information from local people in Sri Lanka and Maldives as well as from Greek eyewitnesses in Thailand.

\begin{tabular}{|c|c|c|c|c|}
\hline $\begin{array}{l}\text { Personal } \\
\text { Data }\end{array}$ & Name & $\begin{array}{l}\text { Sex/age: } \\
\mathrm{M}(\mathrm{F}) /\end{array}$ & Occupation & $\begin{array}{l}\text { Telephone } \\
\text { /fax/e-mail }\end{array}$ \\
\hline $\begin{array}{l}\text { Earthquake } \\
\text { Info (a) }\end{array}$ & $\begin{array}{l}\text { Time: } \\
\text { hh:mm }\end{array}$ & Place & $\begin{array}{l}\text { Indoor: } \\
\text { Yes or No }\end{array}$ & $\begin{array}{l}\text { Outdoor: } \\
\text { Yes or No }\end{array}$ \\
\hline $\begin{array}{l}\text { Earthquake } \\
\text { Info (b) }\end{array}$ & $\begin{array}{c}\text { Indoor (Yes): } \\
\text { type of } \\
\text { building/Floor: }\end{array}$ & $\begin{array}{c}\text { Description of } \\
\text { perceptibility }\end{array}$ & $\begin{array}{c}\text { Other } \\
\text { Comments }\end{array}$ & \\
\hline $\begin{array}{c}\text { Earthquake } \\
\text { Info (c) }\end{array}$ & Outdoor (Yes): & $\begin{array}{l}\text { Description of } \\
\text { perceptibility }\end{array}$ & $\begin{array}{c}\text { Other } \\
\text { Comments }\end{array}$ & \\
\hline $\begin{array}{l}\text { Tsunami } \\
\text { Info (a) }\end{array}$ & Time: hh:mm & Place & $\begin{array}{c}\text { Initial sea } \\
\text { movement/ } \\
\text { Inundation }(d) / \\
\text { Max. water level }\end{array}$ & $\begin{array}{c}\text { Description about } \\
\text { tsunami effects }\end{array}$ \\
\hline $\begin{array}{l}\text { Tsunami } \\
\text { Info (b) }\end{array}$ & $\begin{array}{c}\text { Number of } \\
\text { waves observed }\end{array}$ & $\begin{array}{l}\text { Wave inter- } \\
\text { arrival times }\end{array}$ & $\begin{array}{c}\text { Biggest wave } \\
\text { observed }\end{array}$ & $\begin{array}{l}\text { Which wave caused } \\
\text { Max. inundation }\end{array}$ \\
\hline
\end{tabular}

\section{References}

Fujima, K., T. Tomita, K. Honda, Y. Shigihara, H. Nobuoka, M. Hanzawa, H. Fujii, H. Ohtani, S. Orishimo, M. Tatsumi, and S. Koshimura, Preliminary report on the survey results of 26/12/2004 Indian Ocean Tsunami in the Maldives, 99 pp., April 2005.

Intergovernmental Oceanographic Commission (IOC), Post-tsunami survey field guide, First Edition, Manuals and Guides, 37, UNESCO, 23 pp. +2 annexes, 1998.

Liu, P. L.-F, P. Lynett, H. Fernando, B. E. Jaffe, H. Fritz, B. Higman, R. Morton, J. Goff, and C. Synolakis, Observations by the international tsunami survey team in Sri Lanka, Science, 308, 1595, 2005.

Papadopoulos, G. A. and K. Satake (Eds.), Proceedings of the 22nd IUGG Tsunami Symposium, Chania, Crete Is., 27-29 June, 2005, 330 pp., 2005.

Papadopoulos, G. A., R. Caputo, B. McAdoo, S. Pavlides, V. Karastathis, A. Fokaefs, and S. Valkaniotis, The Indian catastrophic tsunami of 26 December 2004: Field observations and eyewitnesses accounts from Sri Lanka, Maldives islands and Thailand, European Geosciences Union General Assembly, Vienna, Austria, 24-29 April 2005.

G. A. Papadopoulos (e-mail: g.papad@gein.noa.gr), R. Caputo, B. McAdoo, S. Pavlides, V. Karastathis, A. Fokaefs, K. Orfanogiannaki, and S. Valkaniotis 